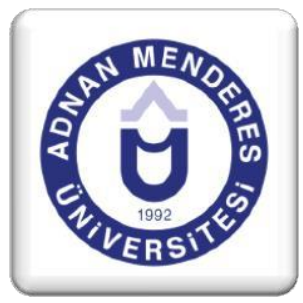

\section{Özel Eğitim II Dersinin Demirel'in Analitik Program Değerlendirme Modeline Göre Değerlendirilmesi: Adnan Menderes Üniversitesi Aydın Meslek Yüksekokulu Örneği}

Nurtaç ÜSTÜNDAĞ ${ }^{1}$, Beylü KARAYAZGAN ${ }^{2}$, Burcu HANCI YANAR ${ }^{3}$, Murat ÇIRAKOĞLU ${ }^{4}$, Kerim GÜNDOĞDU

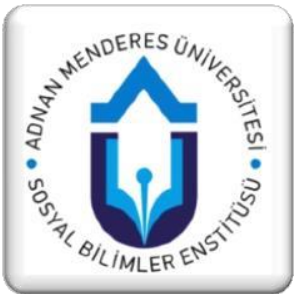

\title{
ÖZET
}

$\mathrm{Bu}$ araştırmanın amac1, Adnan Menderes Üniversitesi Çocuk Gelişimi Bölümü Özel Eğitim II dersi öğretim programı uygulamalarını, Demirel'in Analitik Program Değerlendirme Modeli temel alınarak, öğretim elemanı ve öğrenci görüşlerine göre değerlendirmektir. Araştırma nitel betimsel bir çalışmadır. Veriler toplanırken görüşme, anket ve doküman incelemesi tekniklerinden yararlanılmıștır. Dersi veren öğretim elemanının programa ilişkin görüşlerini almak için yarı yapılandırılmış görüşme formu kullanılmıştır. Öğrencilerin görüşleri ise öğrencilere uygulanan anketler ve anketlerde yer alan açık uçlu sorular yoluyla toplanmıştır. Çalışmanın katılımcılarını 20142015 eğitim öğretim yılı ikinci döneminde Aydın ili Adnan Menderes Üniversitesi Meslek Yüksekokulu Çocuk Gelişimi Bölümünde Özel Eğitim II dersini veren öğretim elemanı ve bu dersi alan 34 öğrenci oluşturmaktadır. Elde edilen verilerin analizi yapılırken içerik analizi yöntemine başvurulmuştur. Araştırma sonucunda, öğretim elemanının dersin hedefleri, içeriği, öğrenme-öğretme ve değerlendirme süreçlerine ilişkin olumlu görüşler belirttiği, sınıf ortamı ve dersin süresini ise olumsuz değerlendirdiği sonucuna ulaşılmıștır. Öğrenciler ise dersin hedefleri, ders süresince yapılan etkinlikleri ve değerlendirme sürecini genel olarak olumlu bulmuşlardır. Dersin içeriğine ve derste kullanılan materyallere ilişkin ise hem olumlu hem de olumsuz görüşler bulunmaktadır.

Anahtar Kelimeler: Program Değerlendirme, Özel Eğitim, Analitik Program Değerlendirme Modeli

\section{Evaluation of Special Education II Course According to Analytical Curriculum Evaluation: Adnan Menderes University Vocational High School}

\begin{abstract}
The aim of this study is to evaluate Special Education II Course Curriculum at Child Development Department of Adnan Menderes University in the context of Demirel Analytical Evaluation Model in terms of opinions of undergraduate students and the instructor. This study is a qualitative descriptive study. While developing data, interview, questionnaire and document analysis techniques have been used in it. Opinions of the instructor have been taken by a semi structured interview form. In addition to that, opinions of undergraduate students have been collected by the questionnaires and by open ended questions in it. Participants of the study consist of the instructor who lectures Special Education II course at Child Development Department of Adnan Menderes University in the second term of 2014-2015 education year and 34 university students who takes this class in the department. The content analysis was used for analyzing obtained data. As a result of the research, it was found that the instructor had positive opinions on the course objectives, content, learning-teaching process and evaluation process, and had negative opinions on the class environment and course duration. The opinions of the students on the objectives of the course, the activities performed during the course and the evaluation process were generally positive. There are both positive and negative opinions regarding the content of the course and the materials used in the course.
\end{abstract}

Keywords: Curriculum Evaluation, Special Education, Analytical Curriculum Evaluation Model

\footnotetext{
${ }^{1}$ Aras. Gör. Adnan Menderes Üniversitesi, Eğitim Fakültesi, Aydın.

${ }^{2}$ Doktora öğrencisi, Adnan Menderes Üniversitesi Eğitim Programları ve Öğretim ABD, Aydın.

${ }^{3}$ Doktora öğrencisi, Adnan Menderes Üniversitesi Eğitim Programları ve Öğretim ABD, Aydın.

${ }^{4}$ Doktora öğrencisi, Adnan Menderes Üniversitesi Eğitim Programları ve Öğretim ABD, Aydın.

${ }^{5}$ Prof. Dr., Adnan Menderes Üniversitesi Eğitim Programları ve Öğretim ABD, Aydın.
} 


\section{Giriş}

Program geliştirme sürecini tamamlayıcı bir aşama olan program değerlendirme, elde edilen sonuçlara göre yeni gelişmelere imkân tanır. Program değerlendirmenin eğitim sürecinde iki temel amaca bağlı olarak yapıldığı söylenebilir. Bunlardan ilki, öğrencilerin başarılarını değerlendirerek dersin hangi öğrenciler tarafından ne kadar öğrenildiğine karar vermek; ikincisi ise eğitim programlarının etkinliğini görerek hakkında yorum yapmak, yargıda bulunmak ve varsa aksaklıklarını saptamaktır. Bu saptamalar esnasında, karşılaşılan sorunlar belirlenerek gerekli düzeltmeler yapılabilmektedir ( Erden ve Akman, 2001).

Stufflebeam, Madaus ve Kellaghan (2000) program değerlendirmenin dinamik bir iş olmakla beraber henüz olgunlaşmamış olduğunu savunurlar. Çünkü program değerlendirme için araştırma yapılmalı, eğitim ve mali destek sağlanmalıdır. Bu bağlamda, program değerlendirmeyi sadece kararlar ve amaçlar bütünü olarak görmemektedirler. Öte yandan, Ornstein ve Hunkins (2004) program değerlendirmeyi belli başlı kararlara bağlamaktadır. Programa devam edilmesi, programın gözden geçirilmesi veya bitirilmesi ve yerine yeni bir programın geliştirilmesi, bu kararlar arasındadır. Program değerlendirme aşamasında izlenecek sıra Demirel (2007: 172) tarafından şu şekilde gösterilmektedir:

1. Uygulamanın planlanmasi, hedeflerin belirlenmesi

2. Deneme yapılacak okulların ve sınıfların seçilmesi

3. Okul yöneticisi ve öğretmenlerin seçimi

4. Okul yöneticisi ve öğretmenlere uygulanacak programın tanıtılmas1

5. Hazırlanan program ve öğretim materyallerinin değerlendirilmesi

Program değerlendirme sürecinin planlanması, organize edilebilmesi ve değerlendirme sürecinin gerçekleşebilmesi için program değerlendirme modellerine ihtiyaç duyulmaktadır. Stufflebeam, Madaus ve Kellaghan (2000), program değerlendirme modeli türlerini üç temel gruba ayırmaktadır:

1. Soru ve metoda dayalı değerlendirme modelleri

2. Gelişme ve sorumluluğa dayalı değerlendirme modelleri

3. Sosyal gündeme dayalı modeller/taraflılık modelleri

Soru ve metoda dayalı değerlendirme modelleri, cevaplar üzerinden programın uygulanabilirliğini değerlendirmeye yeterli olabilecek soruları içermeye; gelişme sorumluluğa dayalı değerlendirme modelleri, bir programın öğretim programlarıyla birlikte oluşturduğu sistemi değerlendirmeye ve geliştirmeye; sosyal gündeme dayalı modeller ise programları hem paydaş hem de uzmanların bakış açılarını kullanarak değerlendirmeye odaklanır (Erden, 1998). Bazı program değerlendirme modelleri doküman analizine önem verirken ve eğitim programlarının kendisine odaklanırken bazıları da öğrenci başarısına odaklanmakta ve programların amaçlarına ve öğrenme çıktılarına önem vermektedir. $\mathrm{Bu}$ nedenle, program değerlendirmede farklı yaklaşımlar ve farklı program değerlendirme modelleri bulunmaktadır. Stufflebeam (1999), 22 farklı program değerlendirme modeli olduğunu belirtmektedir. Belli başlı bazı modeller şu şekilde sıralanabilir:

1. Tyler'ın Hedefe Dayalı Değerlendirme Modeli

2. Metfessel-Michael Değerlendirme Modeli

3. Provus'un Farklar Yaklaşımı ile Değerlendirme Modeli 
4. Stake'in Uygunluk Olasılık Modeli

5. Stuflebeam'in Bağlam- Girdi-Süreç ve Ürün Modeli

6. Stuflebeam Toplam Değerlendirme Modeli

7. Eisner'in Eğitsel Eleştiri Değerlendirme Modeli

8. Stake'in İhtiyaca Cevap Verici Program Değerlendirme Modeli

Ülkemizde de Demirel tarafından 2006 yılında geliştirilen Analitik Program Değerlendirme Modeli'nin program analizi ve paydaş/yararlanıcı görüşleri olmak üzere iki temel boyutu bulunmaktadır. Birinci boyutta; programın kendisi ve programla ilgili yazılı materyaller, ikinci boyutunda ise programdan etkilenen paydaşların görüşleri bulunmaktadır. Modelde her iki boyutta da veri kaynaklarına ve AR-GE çalışmaları ile programın değerlendirildikten sonra sürekli olarak geliştirmesine yer verilmektedir. Modelin hem ilk hem de ikinci boyutunda 'bağlam', 'hedef', 'içerik', 'öğrenme-öğretme süreci', 'ölçme ve değerlendirme' eğitim programı boyutları ele alınmaktadır (Demirel, 2014).

Modelin ilk boyutunda program tasarısıyla başlanan program analizi bulunmaktadır. Böylelikle programın dayandığı temel felsefe, merkeze alınan öğrenme kuramları ile program öğeleri (hedef, içerik, süreç ve sınama durumları) arasındaki ilişkiler sırayla incelenmekte, tasarının analizi yapıldıktan sonra ise mevcut durumun analizi yapılmaktadır. SWOT analizinin bu aşamada faydalı olacağı düşünülmektedir. Bu sayede, programın güçlü, zayıf yönleri ile program uygulamasındaki olanakları ve tehditleri irdelenebilmektedir. $\mathrm{Bu}$ aşamada önerilen bir diğer önemli unsur program tasarısı hazırlanırken yapılan ihtiyaç analizi çalışmasının değerlendirilmesidir. En son aşama olarak, hazırlanan programın girdi, süreç ve çıtı boyutunda değerlendirilmesinin program dokümanlarının incelenmesiyle birlikte yapılması uygun görülmektedir. Programı uygulayacak paydaş görüşlerinin her birinin ayrı ayrı değerlendirilmesinin önerildiği programın ikinci boyutunda; sırasıyla programla ilgili alan uzmanları ile program geliştirme uzmanlarının görüşlerinden başlanarak, öğretmen, öğrenci, yönetici, müfettiş, veli ve sivil toplum örgütlerinin görüşlerinin alınması söz konusudur. Bu görüşlerin alınmasında gözlem, anket, görüşme ve test gibi çeşitli araçlar kullanılabilir (Demirel, 2007).

Hem programla ilgili veriler hem de paydaş görüşlerinden elde edilen veriler temel alınarak programın yeterliliği hakkında bir karara varılıp, elde edilen sonuca göre programın uygulanmasına geçilmesi veya belirlenen eksiklikler varsa bu eksiklerin yeniden gözden geçirilerek giderilmesi ve iyileştirilmesi de önerilen bir başka önemli noktadır (Demirel, 2007). Bu çalışmada da Demirel'in Analitik Program Değerlendirme Modeli temel alınarak paydaş görüşleri ile programın öğelerinin değerlendirilmesi söz konusudur.

\subsection{Araştırmanın Amacı}

$\mathrm{Bu}$ araştırmanın amacı, programa süreklilik kazandırabilmesi, program uygulamalarının hatalı ve eksik kalan yönlerine 1 şık tutulabilmesi, öğretim elemanı ve öğrencilerin görüşlerine ve saptanan gereksinimlerine göre programın geliştirilebilmesine kaynaklık edecek bulgulara ulaşabilmek üzere Adnan Menderes Üniversitesi Çocuk Gelişimi Bölümü Özel Eğitim II dersi öğretim programı uygulamalarını, Demirel'in Analitik Program Değerlendirme Modeli temel alınarak, öğretim elemanı ve öğrenci görüşlerine göre değerlendirmektir.

Bu bağlamda, 'Özel Eğitim II' dersine ilişkin olarak, öğretim elemanının ve öğrencilerin amaçların ve içeriğin öğrenci düzeyine uygunluğu; öğrenme ortamı, yöntem ve teknikler; 
ölçme değerlendirme süreci; derste yaşanan zorluklar ve çözüm yolları açısından görüşleri nelerdir? Sorusu araştırmanın başlıca problem cümlesini oluşturmaktadır

\subsection{Araştırmanın Önemi}

Araştırma, Özel Eğitim II dersindeki uygulamaların verimliliğinin artırılması ve programın gereksinimlerinin karşılanması için yapılması gereken değişikliklerin belirlenmesi açısından önem taşımaktadır. Ayrıca, bu çalışmayla öğretim elemanı ve öğrencilerin dersle ilgili ihtiyaç, hedef, yaklaşım ve görüşlerini göz önünde bulundurarak dersin etkililiğinin artmasına katkıda bulunacak bulgulara ulaşılabileceği düşünülmektedir.

\section{Yöntem}

\subsection{Araştırmanın Modeli}

Bu araştırma 2014-2015 öğretim yılında Adnan Menderes Üniversitesi Meslek Yüksekokulu Çocuk Gelişimi Bölümünde okutulan Özel Eğitim II dersinin programını öğretim elemanı ve öğrenci görüşlerinden yararlanarak değerlendirmek için yapılan nitel içerikli betimsel bir araştırmadır. Betimsel araştırmalarda araştırmaya konu olan olay, birey ya da nesne kendi koşulları içinde ve olduğu gibi tanımlanmaya çalışılır. Olanı herhangi bir şekilde değiş̧irme etkileme çabası gösterilmez (Karasar, 2004). Nitel araştırmada veri toplama yöntemlerinin artıları ve eksileri göz önünde bulundurularak birden fazla yöntem araştırma desenine dahil edilebilir. Böylece veri çeşitlemesi sağlanarak elde edilen bulguların geçerlik ve güvenirliğini arttırma amaçlanır (Yıldırım ve Şimşek, 2011).Çalışmanın araştırma problemleri çerçevesinde veriler toplanırken görüşme, açık uçlu anket ve doküman incelemesi tekniklerinden yararlanılmıştır. Dersi veren öğretim elemanının programa ilişskin görüşlerini almak için yarı yapılandırılmış görüşme yapılmıştır. Öğrencilerin görüşleri ise öğrencilere uygulanan açık uçlu anketler yoluyla toplanmıştır.

\subsection{Katılımcilar}

Çalışmanın katılımcılarını Adnan Menderes Üniversitesi Meslek Yüksekokulu'nda görev yapmakta olan bir öğretim elemanı ile burada öğrenim görmekte olan 34 öğrenci oluşturmaktadır. Araştırmaya katılan öğretim elemanı; Adnan Menderes Üniversitesi Meslek Yüksekokulu Çocuk Gelişimi Bölümü’nde görev yapmakta olan, 2014-2015 eğitim öğretim yılı bahar yarıyılında Özel Eğitim II dersini yürütmekte olan bir öğretim görevlisidir. Araştırmaya katılan öğrenciler ise; 2014-2015 eğitim öğretim yılı bahar yarıyılında Özel Eğitim II dersini alan 34 öğrencidir. Özel Eğitim II dersi, meslek yüksekokulunda toplam iki sınıfta okutulmaktadır. Sınıflardan biri birinci öğretim diğeri ise ikinci öğretim öğrencilerinden oluşmaktadır. Her iki sınıfın dersi de aynı öğretim elemanı tarafından verildiğinden çalışmaya bir öğretim elemanı dâhil olmuştur. Bölümde okuyan erkek öğrenci bulunmamasından dolayı katılımcıların tamamı kız öğrencilerden oluşmaktadır. Dersi alan toplam 58 öğrencinin tamamına ulaşılmış ancak 34 öğrenci eksiksiz olarak geri dönmüş̧ür. Çalışmada amaçlı örnekleme yöntemlerinden uygun örnekleme yöntemi kullanılmıştır.

\subsection{Veri Toplama Araçları}

$\mathrm{Bu}$ çalışmada veri toplama aracı olarak yarı yapılandırılmış görüşme formu ve açık uçlu anket formu kullanılmıştır. Ayrıca programın doküman kısmına ilişkin verilerin toplanmasında Özel Eğitim II dersi programı incelenmiştir. Veri toplama araçlarından yarı yapılandırılmış görüşme formu hazırlanırken Demirel'in Analitik Program Değerlendirme Yaklaşımında yer verdiği maddeler dikkate alınmış ve bu bilgiler 1şığında görüşme soruları hazırlanmıştır. Öğretim elemanına yönelik olarak hazırlanan görüşme formunun kapsam geçerliğini karşılamak adına üç adet program geliştirme uzmanının görüşüne başvurulmuş ve 
maddeler yeniden gözden geçirilmiştir. Görüşme formunda yer almasına karar verilen yedi madde ile forma son şekli verilmiştir. Öğrencilere uygulanan açık uçlu anketlerde de 7 maddeye yer verilmiş ve görüşme soruları ile anketteki sorular birbiriyle örtüştürülmeye çalışılmıştır.

Hazırlanan görüşme formundan yararlanılarak öğretim elemanı ile yarı yapılandırılmış görüşme yapılmıştır. 58 öğrenciye açık uçlu sorulardan oluşan anketler dağıtılmış ve bir hafta sonra toplanmıştır. Anket sorularının kapsam geçerliğini sağlamak adına üç öğretim elemanının görüşlerine yer verilmiştir.

\subsection{Verilerin Analizi}

Veri toplama araçları ile elde edilen verilerin analizi yapılırken içerik analizi yöntemine başvurulmuştur. İlk olarak öğretim elemanı ile yapılan görüşme ses kayıt cihazı ile kayıt altına alınmış ve daha sonra bu kayıtlar metne dökülmüştür. Bu metinlerin içerik analizi yapılırken öncelikle kodlar oluşturulmuş ve bu kodlar temalaştırılmıştır. Nitel araştırmalarda veri analizi için yaygın görüş, verinin anlamlı bölümlere ayrılması ve elde edilen bölümlerin isimlendirilmesi yolu ile kodlar elde edilmesidir. Elde edilen bu kodlar kategoriler ya da temalar altında toplanır. Tema ve kodlar ile bunlar arasındaki ilişkiler, grafikler ya da tablolar kullanılarak sunulur (Creswell, 2003). Çözümleme sonucu ortaya çıkan temalar bulgular kısmında görsellerle sunulmuş ve bu temaların ne kadar tekrarlandığını göstermek için frekans hesaplamaları yapılmıştır. Benzer şekilde öğrencilere uygulanan açık uçlu anketlerin sonuçları da içerik analizine tabi tutulup temalara dönüştürüldükten sonra, frekans hesaplamaları yapılarak bulgular kısmında tablolardan yararlanılarak sunulmuştur.

\section{Bulgular}

\section{1. Öğretim Elemanı Görüşleri}

\subsubsection{Dersin Amaçlarının Öğrenci İhtiyaçlarına ve İçeriğin Öğrenci Düzeyine} Uygunluğu

Özel Eğitim II dersi amaçlarının öğrenci ihtiyaçlarına ve içeriğin seviyelerine uygunluk düzeyine ilişkin öğretim elemanından elde edilen bulgular aşağıda verilmektedir.

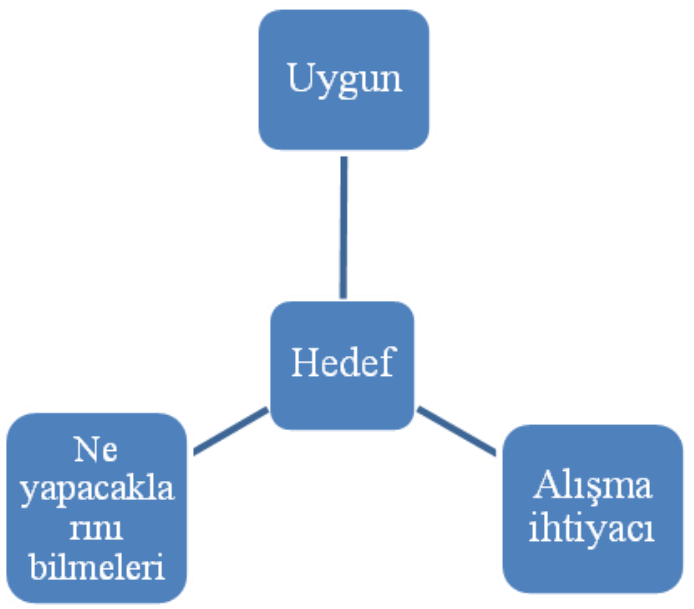

Şekil 3.1. Amaçlara yönelik teması ve kodlar 
Şekil 3.1'de öğretim elemanının Özel Eğitim II dersi hedeflerinin öğrenci ihtiyaçlarına uygunluk düzeyine ilişkin görüşleri yer almaktadır. Buradaki sonuçlar incelendiğinde, öğretim elemanının ders hedeflerinin öğrenci ihtiyaçlarına uygun olduğu görüşünde olduğu görülmektedir. Öğretim elemanı tarafından dersin öğrencilerin engellilere alışma hedefini karşıladığı ifade edilmiştir. Bu konuya ilişkin öğretim elemanının bazı ifadeleri aşağıdaki gibidir:

"Öğrenciler engellilere alışmaya ihtiyaç duyuyorlar ve ne yapacaklarını bu ders ile ögreniyorlar."

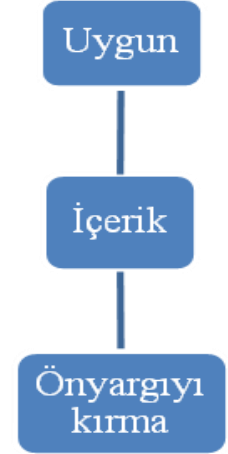

Şekil 3.2. İçerik Teması ve Kodlar

Şekil 3.2'de öğretim elemanının Özel Eğitim II dersi içeriğinin öğrenci düzeyine uygunluk düzeyine ilişkin görüşleri yer almaktadır. Buradaki sonuçlar incelendiğinde, öğretim elemanının ders içeriğinin öğrenci düzeylerine uygun olduğu ve öğrencilerin önyargılarının kırılmasına fayda sağladığı görüşünde olduğu görülmektedir. Bu konuya ilişkin öğretim elemanının bazı ifadeleri aşağıdaki gibidir:

"Öğrenciler engellilere önyargılı olarak geliyorlar ve bu önyargıları kırılınca sikıntıları kalmiyor."

\subsubsection{Kullanılan Yöntem, Teknik, Ortam ve Süre ile İlgili Öğretim Elemanlarının Görüsşleri}

Özel Eğitim II dersinde kullanılan yöntem, teknik, ortam ve süreye ilişkin bulgular aşağıda verilmektedir.
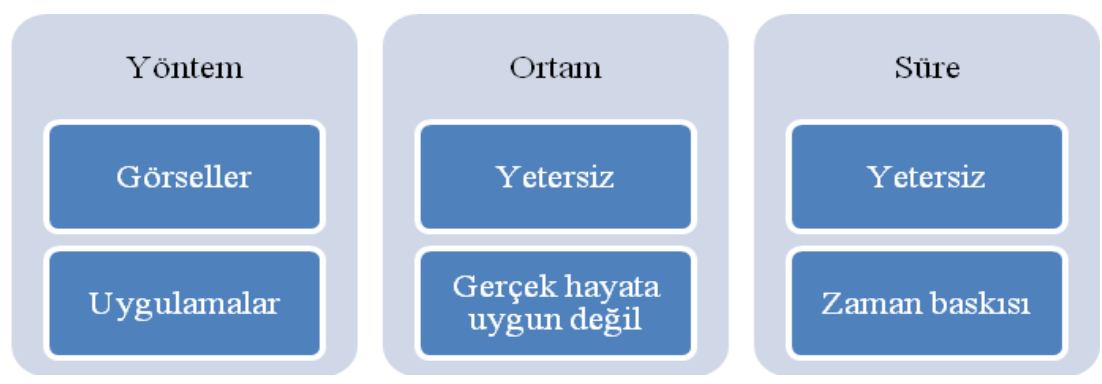

Şekil 3.3. Yöntem, Ortam ve Süre Temaları ile Kodlar

Şekil 3.3'de öğretim elemanının Özel Eğitim II dersinde kullanılan yöntem ve teknikler, ortam ve süre ile ilgili görüşleri yer almaktadır. Buradaki sonuçlar incelendiğinde öğretim elemanının görsellerden yararlandığı, uygulamalı bir ders işlediği görülmektedir. Dersin 
uygulanma ortamının yetersiz olduğu, gerçek hayata uygun olmadığı, sürenin yetersiz olduğu ve zaman baskısı yarattığı ifade edilmiştir. Bu konuya ilişkin öğretim elemanının bazı ifadeleri aşağıdaki gibidir:

"Okullar engellilere uygun değil, öğrenciler yapllan etkinliklerin gerçek hayatta nerede kullanılacăğın bilmiyorlar, haftada 2 saat olan bir ders zaman sıkıntısı yaratıyor."

\subsection{3. Ölçme Değerlendirme Süreci ile İlgili Öğretim Elemanının Görüşleri}

Özel Eğitim II dersindeki ölçme değerlendirme süreci ile ilgili bulgular aşağıda verilmektedir.

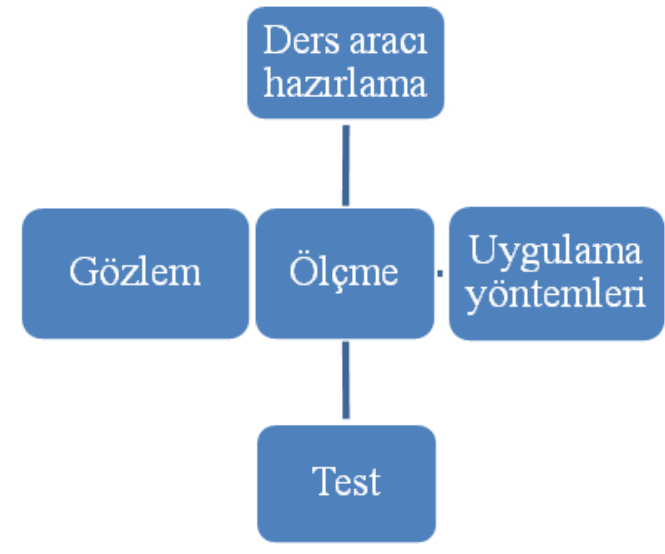

Şekil 3.4. Ölçme Teması ve Kodlar

Şekil 3,4'de öğretim elemanının Özel Eğitim II dersindeki ölçme değerlendirme süreci ile ilgili görüşleri yer almaktadır. Buradaki sonuçlar incelendiğinde öğretim elemanının değerlendirme yöntemi olarak ders aracı hazırlatma, uygulamada kullanılan yöntemleri değerlendirme, test ve gözlemleri değerlendirme yöntemlerini kullandığı görülmektedir. $\mathrm{Bu}$ konuya ilişkin öğretim elemanının bazı ifadeleri aşağıdaki gibidir:

"Öğrenciler belli bir düzeye geldiğinde Menemen Otistik Çocuklar Uygulama Merkezi'ne götürerek gözlem yapmalarını sağlıyorum."

\subsubsection{Derste Yaşanan Zorluklar ve Bunların Çözümüne İlişsin Bulgular}
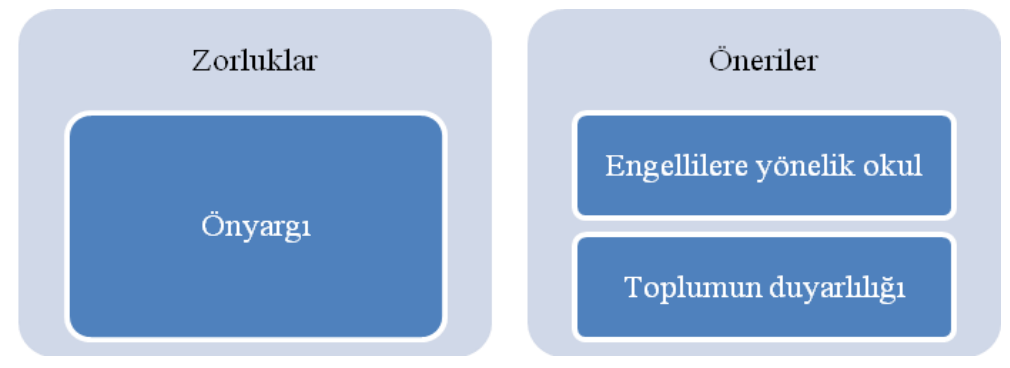

Şekil 3.5. Zorluklar ve Öneriler Teması ile Kodlar

Şekil 3.5'de öğretim elemanının Özel Eğitim II dersinde yaşadığı zorluklar ve çözüm önerilerine ilişkin görüşleri yer almaktadır. Buradaki sonuçlar incelendiğinde öğretim elemanının öğrencilerin önyargısını zorluk olarak değerlendirdiği ve dersin daha etkili hale 
getirilmesi için okulların engellilere yönelik yapılması ve toplumun daha duyarlı olması önerilerinde bulunduğu görülmektedir.

\section{2. Öğrenci Görüsşleri}

Bu bölümde Özel Eğitim II dersini alan öğrencilerin derse ilişkin sorulan sorulara verdikleri cevapların çözümlenmesiyle oluşturulan tema, kategori ve kodlar tablolar halinde yer almaktadır. Amaç, içerik, etkinlik, materyal, ölçme, zorluklar ve öneriler olmak üzere 7 adet temaya ulaşılmış ve temalar Şekil 3,6'da sunulmuştur.

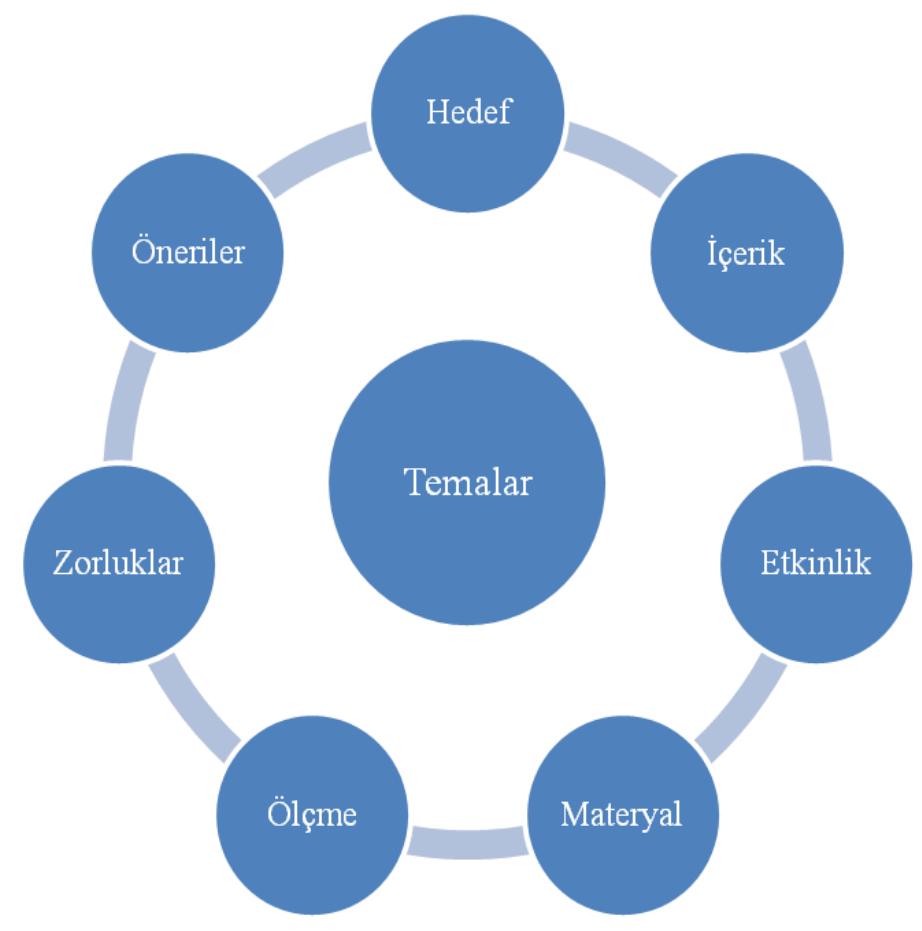

Şekil 3.6. Elde Edilen Temalar

\subsubsection{Amaçların İhtiyaca Cevap Vermesi ve İçeriğin Uygunluğu}

Özel Eğitim II dersi hedeflerinin öğrenci ihtiyaçlarına uygunluk düzeyine ve içeriğin seviyelerine uygunluk düzeyine ilişkin bulgular "Hedef" ve "İçerik" temaları altında çözümlenmiştir.

\subsubsection{Amaçlar Temasına Ait Bulgular}

Özel Eğitim II dersi hedeflerinin öğrenci ihtiyaçlarına uygunluk düzeyine ilişkin bulgular Tablo 3.1.'de sunulmuştur.

Tablo 3.1. Öğrencilerin Dersin Amaçlarının İhtiyaca Uygunluğuna İlişkin Görüşleri

\begin{tabular}{|l|l|l|}
\hline Kategoriler & Davranışlara yol gösterir nitelikte & F \\
\hline \multirow{4}{*}{ Uygun } & İş yaşamını kolaylaştıracak nitelikte & 7 \\
\cline { 2 - 3 } & İhtiyacı karşılar nitelikte & 7 \\
\cline { 2 - 3 } & \multicolumn{1}{|c|}{ Toplam } & $\mathbf{1 9}$ \\
\hline
\end{tabular}


Tablo 3,1'de öğrencilerin Özel Eğitim II dersi amaçlarının ihtiyaçlarına uygunluk düzeyine ilişkin görüşlerinin frekans değerleri yer almaktadır. Tablodaki sonuçlar incelendiğinde, 19 öğrencinin ders amaçlarının ihtiyaçlarına uygun olduğunu ifade ettikleri görülmektedir. Bunun yanında dersin amaçlarına ilişkin olumsuz görüş yer almamaktadır. Ders amaçlarının ihtiyaçlarına uygun olduğunu ifade eden öğrencilerden 7'si engellilere nasıl davranılması gerektiği konusunda yol gösterici olduğunu, 7'si ilerideki iş yaşamlarında yararlı olacak nitelikte olduğunu, 5 'i ise dersin özel eğitime ilişkin ihtiyaçlarını karşıladığını belirtmişlerdir. Bu konuya ilişkin öğrencilerden bazılarının ifadeleri aşağıdaki gibidir:

"Engelli bireyleri tanımamıza ve onlara daha bilinçli yaklaşmamıza sağladı̆̆ katkılar tartışılmaz. Her ne kadar hayat bazen kitaplardaki gibi olmasa da bir yerinden yakalayıp uygulayabiliyor insan. Hayata bakış yelpazenizi genişletip size ışık tutabiliyor." (ö5)

Özel Eğitim II dersinin amaçlar bence ihtiyaçlarıma uygundu. Staj yaparken sinıfimda zihinsel engelli çocuklar vardı. Bu çocuklarda zorlanmadım ama ağır derecede zihinsel engelliler olsaydı o zaman zorlanırdım. O konuda Özel Eğitim II dersinin hedefleri yetersiz kalırdı. (ö33)

\subsubsection{2. İçerik Temasına Ait Bulgular}

Özel Eğitim II dersinde yer alan bilgilerin öğrenci seviyesine uygunluk düzeyine ilişkin bulgular Tablo 3.2.'de sunulmuştur.

Tablo 3.2. Öğrencilerin Ders İçeriğinde Yer Alan Bilgilerin Seviyelerine Uygunluk Düzeyine İlişkin Görüşleri

\begin{tabular}{|c|c|c|}
\hline Kategoriler & & $\mathbf{f}$ \\
\hline Uygun & Anlaşılır & 7 \\
\hline & Toplam & 7 \\
\hline & Seviyenin üstünde & 6 \\
\hline Uygun değil & Çok ayrıntılı & 2 \\
\hline & Toplam & 8 \\
\hline
\end{tabular}

Tablo 3.2'de öğrencilerin Özel Eğitim II dersi içeriğinde yer alan bilgilerin seviyelerine uygunluk düzeyine ilişkin görüşlerinin frekans değerleri yer almaktadır. Tablodaki sonuçlar incelendiğinde, 7 öğrencinin ders içeriğinin seviyelerine uygun olduğunu, 8 öğrencinin ise seviyelerine uygun olmadığını belirttikleri görülmektedir. Ders içeriğinin seviyelerine uygun olduğu yönünde görüş bildiren öğrenciler bilgilerin anlaşılır ve yarar sağlayan nitelikte olduğunu ifade ederken, içeriğin seviyelerine uygun olmadığı görüşünde olan öğrencilerden 6's1 içeriği seviyelerinin üzerinde olarak değerlendirmiş, 2'si ise çok ayrıntılı bilgilerin yer aldığını belirtmişlerdir. $\mathrm{Bu}$ konuya ilişkin öğrencilerden bazılarının ifadeleri aşağıdaki gibidir:

"Seviyemizin üstünde görüyorum. Çünkü tıbbi terimler oldukça fazla. Ama günlük yaşamda karşılaşacağımız sorunları çözmemizde oldukça yararlı." (ö16)

"Bu ders süresince verilen bilgiler seviyemize uygundur. Özel eğitimle ilgili hiçbir şey bilmezken çok şey ögrendim, bence çok yararı oldu. Günlük hayatta kullanılabilirliği açısından bence iyi donatıldım. (ö32)

Özel Eğitim II dersinde yer alan bilgilerin yaşamda kullanılabilirliğine ilişkin bulgular Tablo 3.3 'de sunulmuştur. 
Tablo 3.3. Öğrencilerin Ders İçeriğinde Yer Alan Kullanılabilirliğine İlişkin Görüşleri

\begin{tabular}{|l|l|c|}
\hline Kategoriler & Günlük hayata yardımcı & f \\
\hline \multirow{4}{*}{ Kullanılabilir } & Davranışlara yol gösterir nitelikte & 18 \\
\cline { 2 - 3 } & Farkındalık yaratmada etkili & 14 \\
\cline { 2 - 3 } & İletişim kurmaya yardımcı & 4 \\
\cline { 2 - 3 } & Bakış açısını değiştirmede etkili & 3 \\
\cline { 2 - 3 } & \multicolumn{1}{|c|}{ Toplam } & $\mathbf{4 2}$ \\
\hline
\end{tabular}

Tablo 3.3'de öğrencilerin Özel Eğitim II dersi içeriğinde yer alan bilgilerin kullanılabilirliğine ilişkin görüşlerinin frekans değerleri yer almaktadır. Tablodaki sonuçlar incelendiğinde, içeriğin kullanılabilirliğine ilişkin 42 farkl1 ve olumlu görüş belirtildiği görülmektedir. 18 öğrenci dersin günlük hayatta kullanılabilecek bilgiler içerdiğini, 14 öğrenci engellilere yönelik davranışlarının nasıl olması gerektiğini bu dersle öğrendiklerini, 4 öğrenci engellilere yönelik farkındalık sahibi olduklarını, 3 öğrenci engellilerle nasıl iletişim kurulacağı konusunda yol gösterdiğini, 3 öğrenci ise engellilere bakış açısını değiştirmede etkili olduğunu ve bu sayede onlara herkes gibi davranabilmeyi öğrendiklerini ifade etmişlerdir. Bu konuya ilişkin öğrencilerden bazılarının ifadeleri aşağıdaki gibidir:

"Anlaşıllıllğ̆ kolay, içeriği tam olan bir dersti. Meslek hayatımda bu ders sayesinde engelli bireylerin kaynaştırılmasında zorluk çekmeyeceğime inanıyorum." (ö31)

“Özel eğitim hayatın her yerinde var. Son derece kullanılabilir bilgilerdi.”(ö29)

\subsection{2. Öğrenme Ortamı, Yöntem ve Tekniklere Ait Bulgular}

Özel Eğitim II dersi süresince yapılan etkinliklerin etkililiğine, kullanılan ortam, araç ve gereçlerin uygunluğuna ilişkin bulgular "Etkinlik" ve "Materyal" temaları altında çözümlenmiştir.

\subsubsection{Etkinlik Temasına Ait Bulgular}

\section{Öğrencilerin Ders Süresince Yapılan Etkinliklerin Etkililiğine İlişkin Görüşleri}

Özel Eğitim II dersi süresince yapılan etkinliklerin etkililiğine ilişkin bulgular Tablo 3.4.'de sunulmuştur.

Tablo 3.4. Öğrencilerin Ders Süresince Yapılan Etkinliklerin Etkililiğine İlişkin Görüşleri

\begin{tabular}{|c|c|c|}
\hline \multicolumn{2}{|l|}{ Kategoriler } & $\mathbf{f}$ \\
\hline \multirow{6}{*}{ Etkili } & Oldukça verimli & 24 \\
\hline & Uygulama dersi etkili & 6 \\
\hline & Alan gezileri etkili & 3 \\
\hline & Öğrenilenlerin pekiştirilmesinde etkili & 3 \\
\hline & Yaparak yaşayarak öğrenmede etkili & 2 \\
\hline & Toplam & 38 \\
\hline
\end{tabular}

Tablo 3.4'de öğrencilerin Özel Eğitim II dersi süresince yapılan etkinliklerin etkililiğine ilişkin görüşlerinin frekans değerleri yer almaktadır. Tablodaki sonuçlar incelendiğinde, etkinliklerin etkililiğine ilişkin 38 farklı ve olumlu görüş belirtildiği görülmektedir. 24 öğrenci dersteki etkinliklerin oldukça verimli olduğunu, 6 öğrenci uygulama (staj) dersinin oldukça etkili olduğunu, 3 öğrenci özel eğitim kurumlarına yapılan gezilerin etkili olduğunu, 3 öğrenci öğrenilenlerin pekiştirilmesinde katkı sağladığını, 3 öğrenci ise yaparak yaşayarak öğrenmeye olanak sağlayarak bilgilerin yalnızca teoride kalmasına engel olduğunu ifade etmişlerdir. Bu konuya ilişkin öğrencilerden bazılarının ifadeleri aşağıdaki gibidir: 
"Dersin hedeflerini gerçekleştirmek için bizlere sağlanan özel eğitim uygulaması bu konuda çok etkili oldu. Yaparak görerek uygulama sağlandl. Menemen otistik çocuklar eğitim merkezine düzenlenen gezi sayesinde de öğrendiğimiz teorik bilgileri pekiştirme firsatı bulduk, etkili oldu." (ö20)

"Özel eğitim kurumlarına yapılan geziler bilgilerin kalıcılığını sağlaması açısından verimli ve güzeldi. Derslerin bu şekilde aktivitelerle daha sik anlatılması gerektiğini düşünüyorum. Sinıf içinde sadece kitaptan ders işlemek bazen sikıcı olabiliyor ve bu da bilgilerin kalıcılı̆̆ını etkiliyor. Ama geziler sırasında ögrenilenler akılda daha kalıcl oluyor." (ö21)

"Bireylere aslında normalmiş gibi davranabilmemizi sağlad. Özel eğitim bence herkesin öğrenmesi gereken bir derstir. Insana hayatın acı ve gerçek yanını gösteriyor." (ö23)

\subsubsection{Materyal Temasina Ait Bulgular}

\section{Görüşleri}

Öğrencilerin Ders Süresince Kullanılan Materyallerin Etkililiğine İliş̧kin

Özel Eğitim II dersi süresince kullanılan materyallerin etkililiğine ilişkin bulgular Tablo 3.5.'te sunulmuştur.

Tablo 3.5. Öğrencilerin Ders Süresince Kullanılan Materyallerin Etkililiğine İlişkin Görüşleri

\begin{tabular}{|l|l|c|}
\hline Kategoriler & Kalıcılıkta etkili & f \\
\hline \multirow{4}{*}{ Etkili } & Anlamayı kolaylaştırıcı & 9 \\
\cline { 2 - 3 } & Bakış açısını değiştirmede etkili & 3 \\
\cline { 2 - 3 } & Kısmen etkili & 2 \\
\cline { 2 - 3 } & \multicolumn{1}{|c|}{ Toplam } & 1 \\
\hline \multirow{4}{*}{ Etkili değil } & Ders kitabı dışında materyal yoktu & 5 \\
\cline { 2 - 3 } & Ders kitabı çok ayrıntılı & 2 \\
\cline { 2 - 3 } & Öğrenme ortamı uygun değil Toplam & $\mathbf{9}$ \\
\cline { 2 - 3 } & & \\
\hline
\end{tabular}

Tablo 3.5'te öğrencilerin Özel Eğitim II dersi süresince kullanılan materyallerin etkililiğine ilişkin görüşlerinin frekans değerleri yer almaktadır. Tablodaki sonuçlar incelendiğinde, materyallerin etkililiğine ilişkin 15 olumlu ve 9 olumsuz görüş belirtildiği görülmektedir. 9 öğrenci dersteki materyallerin bilgilerin kalıcılığında etkili olduğunu, 3 öğrenci konuları anlamayı kolaylaştırmada etkili olduğunu, 2 öğrenci özellikle görsel materyallerle zenginleştirilen dersin bakış açılarında değişimi sağladığını, 1 öğrenci kısmen etkili olduğunu ifade etmişlerdir. Olumsuz görüş bildiren öğrencilerden 5'i ders kitabı dişında materyal kullanılmadığını, 2 öğrenci ders kitabını çok ayrıntılı bulduklarını, 2 öğrenci ise dersin işlendiği sınıf ortamının uygun olmadığını belirtmişlerdir. $\mathrm{Bu}$ konuya ilişkin öğrencilerden bazılarının ifadeleri aşağıdaki gibidir:

"Ders işlediğimiz ortamın geniş olması, projeksiyon cihazının olmasl, bize rahat ve görsel, işitsel yönden destekleyici bir ögrenme ortamı açısından oldukça katkı sağladı̆̆ını düşünüyorum." (ö29)

"Derste kullanılan özel eğitim kitabı bana yeterli geldi ama kaynaklar çoğaltılabilir. Dersin işlendiği ortam uygun değildi." (ö33) 


\section{Görüşleri}

3.2.3. "Derste Kullanılan Ölçme Değerlendirme Süreci İle İlgili Öğrenci

Özel Eğitim II dersi süresince kullanılan ölçme ve değerlendirme sisteminin etkililiğine ilişkin bulgular "Ölçme" teması altında çözümlenmiştir.

\subsubsection{1 "Ölçme" Temasına Ait Bulgular: Ölçme ve Değerlendirme Sistemine İlişkin Görüşler}

Özel Eğitim II dersi süresince kullanılan ölçme ve değerlendirme sisteminin etkililiğine ilişkin bulgular Tablo 3.6.'da sunulmuştur.

Tablo 3.6. Öğrencilerin Dersin Ölçme ve Değerlendirme Sistemine İlişkin Görüşler

\begin{tabular}{|c|c|c|}
\hline \multicolumn{2}{|c|}{ Kategoriler } & f \\
\hline \multirow{4}{*}{ Etkili } & Kismen etkili & 14 \\
\hline & Oldukça etkili & 6 \\
\hline & Adil & 2 \\
\hline & Toplam & 22 \\
\hline \multirow{2}{*}{ Diğer } & Fikrim yok & 4 \\
\hline & Etkili değil & 2 \\
\hline
\end{tabular}

Tablo 3.6'da öğrencilerin Özel Eğitim II dersinin ölçme ve değerlendirme sistemine ilişkin görüşlerinin frekans değerleri yer almaktadır. Tablodaki sonuçlar incelendiğinde, ölçme ve değerlendirme sistemine ilişkin 22 olumlu ve 2 olumsuz görüş belirtildiği görülmektedir. 4 öğrenci ise herhangi bir değerlendirmede bulunmamıştır. 14 öğrenci ölçme ve değerlendirme sistemini kısmen etkili bulduklarını, 6 öğrenci sistemin oldukça etkili olduğunu ve 2 öğrenci adil bir değerlendirme sistemi olduğunu ifade etmişlerdir.. Bu konuya ilişkin öğrencilerden bazılarının ifadeleri aşağıdaki gibidir:

"Yapılan değerlendirmelerin tek boyutlu olmadı̆̆ını düşünüyorum. Çünkü bazılarımı teorikte iyiyken bazılarımı uygulamada iyi oluyor. Bu dönem hem teoriğe dayalı sınavların olmasını hem de stajyerlik yaptığımı kurumdaki ve özel eğitim hocamızın gözlemler ve verdiği etkinliklerdeki kanaatleri sonucu değerlendirmelerin adil olduğunu düşünüyorum. ” (ö29)

3.2.4. “Özel Eğitim II Dersinde Yaşanan Zorluklar ve Bunların Çözümüne İlişkin Öğrenci Görüşleri Nelerdir?” Sorusuna Ait Bulgular

Özel Eğitim II dersi süresince karşılaşılan zorluklar ve çözüm önerilerine ilişkin bulgular "Zorluklar" ve "Öneriler" temaları altında çözümlenmiştir.

\section{Zorluklar}

\subsubsection{1. "Zorluklar" Temasına Ait Bulgular: Ders Süresince Karşıllaşılan}

Özel Eğitim II dersi süresince karşılaşılan zorluklara ilişkin bulgular Tablo 3.7.'de sunulmuştur.

Tablo 3.7. Öğrencilerin Ders Süresince Karşılaştıkları Zorluklara İlişkin Görüşleri

\begin{tabular}{|l|l|c|}
\hline Kategoriler & Terimleri anlamak & f \\
\cline { 2 - 3 } Ders süreci & Konuları anlamak & 8 \\
\cline { 2 - 3 } & Ders kitaplarının ayrınt1l1 olmas1 & 3 \\
\cline { 2 - 3 } & Ders sırasında yapılan etkinlikler & 2 \\
\hline
\end{tabular}




\begin{tabular}{|l|lc|c|}
\hline & & Toplam & $\mathbf{1 5}$ \\
\hline \multirow{4}{*}{ Bireysel } & Korku duyma & 5 \\
\cline { 2 - 4 } & İletişim güçlüğ̈̈ & 2 \\
\cline { 2 - 4 } & Psikolojik zorlanma & 1 \\
\cline { 2 - 4 } & & $\mathbf{9}$ \\
\hline Diğer & Zorlanma yok & $\mathbf{9}$ \\
\hline
\end{tabular}

Tablo 3.7'de öğrencilerin Özel Eğitim II dersi süresince karşılaştıkları zorluklara ilişkin görüşlerinin frekans değerleri yer almaktadır. Tablodaki sonuçlar incelendiğinde, öğrencilerin ders süreci ve bireysel ilişkilere yönelik zorluklardan söz ettikleri görülmektedir. 8 öğrenci ders sürecinde kullanılan tıbbi terimleri anlamakta zorlandıklarını, 3 öğrenci bazı konuları anlamakta güçlük çektiklerini, 2 öğrenci ders kitabının çok ayrıntılı olmasından dolayı zorluklar yaşadıklarını ve 2 öğrenci ders sırasında materyal yapma etkinliklerinden dolayı zorlandıklarını ifade etmişlerdir. 5 öğrenci bu dersi almadan önce engelli bireylere nasıl davranacaklarına yönelik korku yaşadıklarını, 2 öğrenci engelli bireylerle iletişim kurmada güçlük çektiklerini, 1 öğrenci ise engelli bireylerle bir arada olmanın psikolojik olarak zorladığını belirtmişlerdir. 9 öğrenci ise ders süresince herhangi bir zorluk yaşamadıklarını ifade etmişlerdir. Bu konuya ilişkin öğrencilerden bazılarının ifadeleri aşağıdaki gibidir:

"Stajda bazı ögrencileri anlayamadım, korktuğum anlar oldu ama sonradan hepsine alıştım." (ö12)

Bazı bilgilerde çok ayrıntıya inilmişti, Latince kelimeler vardı. Bunlara çalışırken zorluk çektim." (ö10)

\section{Öneriler \\ 3.2.4.2. “Öneriler” Temasına Ait Bulgular: Dersin Daha Etkili Olması İçin}

Özel Eğitim II dersinin daha etkili hale getirilmesi için önerilerine ilişkin bulgular Tablo 3.8.'de sunulmuştur.

Tablo 3.8. Öğrencilerin Dersin Daha Etkili Hale Getirilmesine İliş̧kin Önerileri

\begin{tabular}{|c|c|c|c|}
\hline Kategoriler & & & $\mathbf{f}$ \\
\hline \multirow{5}{*}{$\begin{array}{l}\text { Ders araç } \\
\text { gereci ve ortam }\end{array}$} & Materyal artırılmalı & & 17 \\
\hline & Özel eğitim kurumları daha çok ziyaret edilmeli & & 10 \\
\hline & Ders kitab1 ve konular sadeleştirilmeli & & 4 \\
\hline & Okulun bir bölümü özel eğitim için ayrılmalı & & 1 \\
\hline & & Toplam & 32 \\
\hline \multirow{6}{*}{ Yöntem } & Derse engelli bireyler konuk olmalı & & 6 \\
\hline & Etkinlikler artırılmalı & & 6 \\
\hline & Daha çok örnek verilmeli & & 2 \\
\hline & Daha dikkat çekici olmalı & & 2 \\
\hline & Farklı öğretim yöntemleri kullanılmalı & & 2 \\
\hline & & Toplam & 18 \\
\hline
\end{tabular}

Tablo 3.8'de öğrencilerin Özel Eğitim II dersinin daha etkili hale getirilmesine ilişkin önerilerinin frekans değerleri yer almaktadır. Tablodaki sonuçlar incelendiğinde, öğrencilerin ders araç gereci ve ortam ile öğretim yöntemine ilişkin öneriler getirdikleri görülmektedir. On yedi öğrenci derste daha fazla materyal kullanılması, 10 öğrenci özel eğitim kurumlarının daha s1k ziyaret edilmesi, 4 öğrenci ders kitabı ve konuların sadeleştirilmesi, 1 öğrenci ise okulun bir bölümünün özel eğitim dersi ve engelli bireyler için ayrılması yönünde öneri getirmişlerdir. 6 öğrenci derse engelli bireylerin daha çok gelerek 
dersi zenginleştirmesi, 6 öğrenci derse yönelik etkinliklerin artırılması, 2 öğrenci konuların daha çok örnek verilerek işlenmesi, 2 öğrenci dersin daha dikkat çekici olacak şekilde işlenmesi, 2 öğrenci farklı öğretim yöntemlerinin bir arada kullanılarak öğrencilerin etkin katılımının sağlanması gerektiği yönünde öneride bulunmuşlardır. Bu konuya ilişkin öğrencilerden bazılarının ifadeleri aşağıdaki gibidir:

"Dersin etkili olabilmesi için teorik bilgilerin yanı sıra uygulamalı eğitim verilir ve ögrencilerin gözlemlemesi sağlanırsa daha etkili ve okulda kalıcı olacağını düşünüyorum.” (ö18)

"Daha çok etkinlik ve çalışmalar yapılması, araç gereç ve materyallerin kullanılmasını öneriyorum." (ö24)

\section{Sonuç ve Öneriler}

Öğretim elemanının görüşleri doğrultusunda, dersin hedeflerinin öğrenci ihtiyaçlarına ve içeriğin seviyelerine uygun olduğu; kullanılan yöntem, teknik, ortam ve süreye ilişkin görsellerden yararlanıldığı, uygulamalı bir ders işlediği, sınıf ortamının yetersiz ve gerçek hayata uygun olmadığı, haftalık ders süresinin yetersiz olduğu, değerlendirme yöntemi olarak ders aracı hazırlatma, uygulamada kullanılan yöntemleri değerlendirme, test ve gözlemleri değerlendirme yöntemlerinin kullanıldığ 1 belirlenmiştir. Benzer şekilde Morberg ve Savolainen (2003) çalışmasında öğretmenlerin engelin ağır olduğu durumlar için sınıf ortamlarını yetersiz olarak değerlendirdiği sonucuna ulaşmıştır. Sucuoğlu (2004) öğretmenlere ve öğrencilere sağlanması gereken destek hizmetleri ile okullarda kaynaştırma uygulamaları için uygun koşulların yetersiz olduğunu, özel eğitim hizmetleri yönetmeliğinde belirtilen ilkeler ve işleyişin gerçekleştirilemediğini belirtmektedir.

Öğretim elemanının öğrencilerinin engelli bireylere karşı önyargısını zorluk olarak değerlendirdiği ve dersin daha etkili hale getirilmesi için okulların engellilere yönelik yapılması ve toplumun daha duyarlı olması önerilerinde bulunduğu görülmektedir. Öğrencilerin tamamına yakını, ders amaçlarının engellilere nasıl davranılması gerektiği konusunda rehber, ilerideki iş yaşamlarında yararlı olacak nitelikte ve dersin özel eğitime ilişkin ihtiyaçlarına uygun olduğunu ifade ettikleri görülmektedir. Bunun yanında öğrenciler dersin amaçlarına ilişkin olumsuz görüş belirtmemişlerdir. Eğitimcilere yönelik olarak yapılan çalışmalarda da benzer şekilde eğitimcilerin engel gruplarına ilişkin bilgi düzeyleri arttığında kendilerini çalışmaya daha istekli ve hazır hissettikleri, engellilere yönelik tutumlarında olumlu yönde gelişmelerin görüldüğü belirtilmektedir (Avramidis, Bayliss ve Burden, 2000; Naor ve Miligram, 1980; Wischnowski, Salmon ve Eaton, 2004; Yoon-Suk, 2010; Zambelli ve Bonni, 2004).

Öğrenciler ders içeriğinin seviyelerine uygunluk düzeyine ilişkin farklı görüşlere sahiptir. Ders içeriğinin seviyelerine uygun olduğu yönünde görüş bildiren öğrenciler bilgilerin anlaşılır ve yarar sağlayan nitelikte olduğunu ifade ederken, içeriğin seviyelerine uygun olmadığı görüşünde olan öğrenciler ise içeriği seviyelerinin üzerinde olarak değerlendirerek, içerikte çok ayrıntılı bilgilerin yer aldığını belirtmişlerdir. Öğrenciler dersin içeriğinin kullanılabilirliğine ilişkin farklı olumlu görüşlere sahiptir. Öğrenciler, dersin içeriğinin günlük hayatta kullanılabilecek bilgiler içerdiğini ve bu sayede engellilere yönelik davranışlarının nasıl olması gerektiğini öğrendiklerini, engellilere yönelik farkındalık sahibi olduklarını, engellilerle nasıl iletişim kurulacağı konusunda yol gösterdiğini ve engellilere bakış açısını değiştirmede etkili olduğunu ve bu sayede onlara herkes gibi davranabilmeyi öğrendiklerini ifade etmişlerdir. Melekoğlu (2013) öğretmen adaylarıyla gerçekleştirdiği çalışmasında Özel Eğitim dersinde sunulan bilgilerin öğretmen adaylarının ilgilerini çektiği, birçok yeni bilgi öğrendiklerini ifade ettikleri sonucuna ulaşmıştır. Altıntaş ve Şengül'ün 
(2014) çalışmalarında Özel Eğitim dersinin öğrencilerin farkındalık düzeylerini arttırdığı ve bakış açılarını olumlu yönde değiştirdiği sonucuna ulaşılmıştır. Şahin ve Güldenoğlu (2013) çalışmalarında katılımcılara sunulan eğitim programının onların engelli bireylere yönelik tutumları üzerinde olumlu etkileri olduğu sonucuna ulaşmışlardır. Başka bir çalışmada öğretmen adaylarının eğitim programlarına özel eğitim uygulamalarının yerleştirilmesinin kaynaştırmayla ilgili bilgi seviyelerini ve özel gereksinimli öğrencilerle karşılaşılması durumunda ne yapacağ ulaşılmıştır (Brown, Welsh, Hill ve Cipko, 2008).

Öğrenciler ders süresince yapılan etkinlikleri genel olarak olumlu bulmuşlardır. Öğrencilerin çoğu dersteki etkinliklerin oldukça verimli olduğunu, bunun yanında uygulama (staj) dersi ve özel eğitim kurumlarına yapılan gezilerin etkili olduğunu, öğrenilenlerin pekiştirilmesinde katkı sağladığını ve yaparak yaşayarak öğrenmeye olanak sağlayarak bilgilerin yalnızca teoride kalmasına engel olduğunu ifade etmişlerdir. Öğretmenlerin kaynaştırma konusunda kendilerinden beklenilenleri karşılayabilmeleri için öncelikle kaynaştırma uygulamasına karşı olumlu tutum geliştirmeleri gerekmektedir (Fırat, 2014). Melekoğlu'nun (2013) çalışmasında benzer şekilde, özel gereksinimli öğrencilerle yürütülen etkileşim çalışmalarının öğretmen adaylarının özel gereksinimli öğrencilere yönelik bakış açılarını olumlu yönde etkilediği sonucuna ulaşılmıştır.

Öğrenciler ders süresince kullanılan materyallerin etkililiğine ilişkin farklı görüşlere sahiptir. Ders süresince kullanılan materyallerin etkililiğine ilişkin olumlu görüş bildiren öğrenciler dersteki materyallerin bilgilerin kalıcılığında ve konuları anlamayı kolaylaştırmada etkili olduğunu, özellikle görsel materyallerle zenginleştirilen dersin bakış açılarında değişimi sağladığını ifade ederken, materyallerin etkililiğine ilişkin olumsuz görüş bildiren öğrenciler ise ders kitabı dışında materyal kullanılmadığını ve ders kitabını çok ayrıntılı bulduklarını, ayrıca sınıf ortamının da ders işlenmesine uygun olmadığını belirtmişlerdir.

Öğrenciler dersin ölçme ve değerlendirme sistemine ilişkin ağırlıklı olarak olumlu ve kısmen olumsuz görüşlere sahiptir. Olumlu görüş bildiren öğrenciler ölçme ve değerlendirme sistemini kısmen etkili, oldukça etkili ve adil olarak ifade etmişlerdir. Olumlu görüşlerin derste yapılan değerlendirmelerin teorik, pratik ve öğretmen gözlemlerine dayalı olmasından kaynaklandığı düşünülmektedir.

Öğrenciler ders sürecinde, kullanılan terimleri ve bazı konuları anlamakta güçlük çektiklerini, ders kitabının çok ayrıntılı olmasından dolayı zorluklar yaşadıklarını ve ders sırasında materyal yapma etkinliklerinden dolayı zorlandıklarını ifade etmişlerdir. Bunun yanında, bireysel ilişkilere yönelik olarak bu dersi almadan önce engelli bireylere nasıl davranacaklarına yönelik korku yaşadıklarını, engelli bireylerle iletişim kurmada güçlük çektiklerini, engelli bireylerle bir arada olmanın psikolojik olarak kendilerini zorladığını belirtmişlerdir. Fırat'ın (2014) araştırmasında Eğitim Fakültesi ile Fen Edebiyat Fakültesinde öğrenim gören ve pedagojik formasyon eğitimi alan öğrencilerinin kaynaştırmaya yönelik düşünceleri arasında anlamlı bir farklılığın olduğu görülmüştür. Eğitim Fakültesi öğrencileri lehine olan bu farklılığın Eğitim Fakültesinin bütün programlarında "Özel Eğitim" dersinin zorunlu ders olarak verilmesi, bunun yanında Sınıf Öğretmenliği programında "İlköğretimde Kaynaştırma”, Rehberlik ve Psikolojik Danışma programında ise "Öğrenme Güçlükleri” ve "Özel Eğitimde PDR Hizmetleri" derslerinin de verilmesinden kaynaklı olabileceği düşünülmektedir. Benzer çalışmalar da bu bulguyu destekler niteliktedir. Stone ve Brown'ın (1986) çalışmalarında kaynaştırma eğitimi alan öğrencilerin sınıf yönetimi becerilerine ve özel gereksinimli çocukların akademik becerilerini artırmaya yönelik daha olumlu bakış açısına sahip oldukları sonucuna ulaşılmıştır. Gözün ve Yıkmış (2004), kaynaştırma eğitim 
programına katılan öğretmen adaylarının, katılmayanlara göre kaynaştırmaya yönelik tutum puanlarının daha yüksek olduğu sonucuna ulaşmışlardır. Bir başka çalışmanın bulgularına göre; lisans eğitimi içerisinde zihinsel engele sahip bireylere yönelik olarak eğitim alan katılımcıların, eğitim almayan katılımcılara oranla engellilere yönelik farkındalık düzeyleri daha yüksektir (Kırımoğlu, Esentürk, İlhan, Yılmaz ve Kaynak, 2016).

Öğrenciler dersin daha etkili hale getirilmesine ilişkin derste daha fazla materyal kullanılması, özel eğitim kurumlarının daha sık ziyaret edilmesi, ders kitabı ve konuların sadeleştirilmesi, okulun bir bölümünün özel eğitim dersi ve engelli bireyler için ayrılması yönünde önerilerde bulunmuşlardır. Ayrıca öğretim yöntem ve tekniklerinin kullanımına ilişkin olarak derse engelli bireylerin daha çok gelerek dersi zenginleştirmesi, derse yönelik etkinliklerin artırılması, konuların daha çok örnek verilerek ve daha dikkat çekici olacak şekilde işlenmesi, farklı öğretim yöntemlerinin bir arada kullanılarak öğrencilerin etkin katılımının sağlanması gerektiği yönünde önerilerde bulunmuşlardır. Yapılan bazı çalışmalarda da kaynaştırmada başarının genel eğitim öğretmenlerinin sınıf atmosferini farklı özelliklere sahip öğrencilere uygun hale getirmelerine, bunun ise öğretmenlerin sahip oldukları yeterliliğe ve isteğe bağlı olduğu belirtilmiştir (Forlin, Douglas ve Hattie, 1996; Forlin, Loreman, Sharma ve Earle, 2009).

Öneriler

1. Dersi veren öğretim elemanı Özel Eğitim II dersinin haftalık ders saatini yetersiz bulmakta ve sınıf ortamını günlük hayata uygun bulmamaktadır. Öğrenciler ise ders süresince daha fazla örnek verilmesini ve etkinliklerin artırılmasını önermektedirler. $\mathrm{Bu}$ sonuçlara yönelik olarak ders saatinin artırılması ve sınıf ortamının günlük yaşama uygun hale getirilecek şekilde düzenlenmesi önerilebilir.

2. Öğretim elemanı okulların engellilere uygun olmadığını belirtmiş ve öğrenciler de okulların bir bölümünün engelliler için ayrılmasını önermişlerdir. Buna bağlı olarak, okulların engellilerin eğitim sürecine katılmalarını kolaylaştıracak ve onların gereksinimlerini karşılayabilecek biçimde yapılandırılması sağlanabilir.

3. Öğrencilerin çoğunluğunun dersin içeriğini yoğun olarak nitelendirmesi sonucundan hareketle ders içeriğindeki konular sadeleştirilerek uygulamaları kolaylaştırıcı hale getirilmesi önerilebilir.

4. Öğrencilerin derse yönelik etkinliklerin artırılması önerilerinden hareketle farklı türde özellik taşıyan özel öğretim kurumlarında daha fazla gözlem, etkinlik ve uygulama firsatı sunulabilir.

5. Öğrencilerin ders süresince zorlandıkları konular dikkate alındığında engelli bireylerle iletişim kurma, bir arada olma ve etkinlikte bulunmanın öğrenciler üstünde oluşturabileceği olumsuz etkilere karşı öğrencilere psikolojik destek sağlanması önerilebilir.

6. Öğrencilerin derste kullanılan yöntem ve tekniklerin artırılmasını önermektedirler. $\mathrm{Bu}$ sonuçtan hareketle derse etkin katılımını sağlayan örnek olay, tartışma, istasyon gibi farklı yöntem ve teknikler kullanılarak dersin daha ilgi çekici bir hale getirilmesi önerilebilir.

7. Öğrencilerin materyallerin zenginleştirilmesi önerileri göz önünde bulundurularak materyal çeşidinin artırılması ve öğrencilerin materyal oluşturma sürecine katılmaları sağlanabilir. 


\section{KAYNAKÇA}

ALTINTAŞ, E. ve ŞENGÜL, S. (2014). Özel eğitim dersinin kaynaştırmaya yönelik tutumlar ve kazanımlar bakımından değerlendirilmesi, E-Kafkas Eğitim Araştırmaları Dergisi, 1(3), 1-12.

AVRAMIDIS, E., BAYLISS, P. and BURDEN, R. (2000). A survey into mainstream teachers' attitudes towards the inclusion of children with special educational needs in the ordinary school one local education authority. Educational Psychology, 20(2), 191-211.

BROWN, K. S., WELSH, L. A., HILL, K. H., and CIPKO, J. P. (2008). The efficacy of embedding special education instruction in teacher preparation programs in the United States. Teaching and Teacher Education, 24(8), 2087-2094.

CRESWELL, J. W. (2003). Qualitative, quantitative, and mixed methods approaches (2nd ed.). Thousand Oaks, CA: Sage.

DEMIREL, Ö. (2007). Kuramdan uygulamaya eğitimde program gelişstirme. (7. Bask1). Ankara: PegemA Yayıncilik.

DEMİREL, Ö. (2014). Eğitimde program geliştirme kuramdan uygulamaya. (21. Bask1). Ankara: PegemA Yayıncilik.

ERDEN, M. (1998). Eğitimde program değerlendirme. Ankara: Anı Yayınc1lık.

ERDEN, M. ve Akman, Y. (2001). Gelişim ve öğrenme. Ankara: Arkadaş Yayınevi.

FIRAT, T. (2014). Farklı eğitim kademelerinde görev yapacak öğretmen adaylarının kaynaştırmaya yönelik tutumlarının incelenmesi. Adlyaman Üniversitesi Sosyal Bilimler Enstitüsü Dergisi, 7(18), 597-628.

FORLIN, C., DOUGLAS, G., and HATTIE, J. (1996). Inclusive practices: How accepting are teachers?. International Journal of Disability, Development and Education, 43(2), 119-133.

FORLIN, C., LOREMAN, T., SHARMA, U., and EARLE, C. (2009). Demographic differences in changing preservice teachers' attitudes, sentiments and concerns about inclusive education. International Journal of Inclusive Education, 13(2), 195-209.

GÖZÜN, Ö. ve YIKMIŞ, A. (2004). Öğretmen adaylarının kaynaştırma konusunda bilgilendirilmelerinin kaynaştırmaya yönelik tutumlarının değişimindeki etkililiği. Ankara Üniversitesi Eğitim Bilimleri Fakültesi Özel Eğitim Dergisi, 5, 65-77.

KARASAR, N. (2005). Bilimsel araştırma yöntemi. Ankara: Nobel Yayın Dağıtım.

KIRIMOĞLU, H., ESENTÜRK, O., ILHAN, E., L., YILMAZ, A. ve KAYNAK, K. (2016). İlköğretim, Özel Eğitim ve Rehabilitasyon Merkezi Öğretmenleri ile Beden Eğitimi ve Spor Öğretmen Adaylarının Zihinsel Engelli Bireylerin Fiziksel Egzersize Katılımlarının Etkilerine Yönelik Farkındalık Düzeylerinin İncelenmesi. Manas Sosyal Araşttrmalar Dergisi, 5(4), 231-244.

MELEKOĞLU, M. A. (2013). Özel gereksinimli öğrencilerle yürütülen etkileşim projesinin genel eğitim öğretmenlerinin kaynaştırma uygulamalarına yönelik olumlu tutum ve farkındalık geliştirmeleri üzerindeki etkilerinin belirlenmesi. Kuram ve Uygulamada Ĕgitim Bilimleri, 13(2), 1053- 1077. 
MORBERG, S., and SAVOLAINEN, H. (2003). Struggling for inclusive education in the North and the South: Educator's perceptions on inclusive education in Finland and Zambia. International Journal of Rehabilitation Research, 26(1), 21-31.

NAOR, M., and MILIGRAM, R. M. (1980). Two preservice strategies for preparing regular class teachers for mainstreaming. Exceptional Children, 46, 292-294.

ORNSTEIN, A. C. and HUNKINS, F. (2004). Curriculum foundations; principles and issues. Boston: Pearson Education.

SAYLOR, J. G. and ALEXANDER, W. M. (1974). Planning curriculum for schools. New York: Holt, Rinehalt and Winston Inc.

STONE, B. and BROWN, R. (1986). Preparing teachers for mainstreaming: Some critical variables for effective preservice programs. Educational Research Quarterly, 11(2), 7-10.

STUFFLEBEAM, D. L. (1999). Foundational models for 21 st century program evaluation. (The Evaluation Center Occasional Papers Series). Western Michigan University. https://www.globalhivmeinfo.org/CapacityBuilding/Occasional\%20Papers/16\%20Fo undational $\% 20$ Models $\% 20$ for $\% 2021$ st $\% 20$ Century\%20Program\%20Evaluation.pdf (Erişim Tarihi: 03.06.2015).

STUFFLEBEAM, D. L., Madaus, G. F. and Kellaghan, T. (2000). Evaluation models viewpoints on evaluational and human services evaluation. Boston / Dordrecht / London: Kluwer Academic Publishers.

SUCUOĞLU, B. (2004). Türkiye'de kaynaştırma uygulamaları: Yayınlar/Araştırmalar (1980-2005)”. Ankara Üniversitesi Eğitim Bilimleri Fakültesi Özel Eğitim Dergisi, 5(2) 15-23 Ankara.

ŞAHIN, F. ve GÜLDENOĞLU, B. (2013). Engelliler konusunda verilen eğitim programının engellilere yönelik tutumlar üzerindeki etkisi. Amasya Üniversitesi Eğitim Fakültesi Dergisi, 2(1), 214-239.

WISCHNOWSKI, M. W., SALMON, S. J. and EATON, K. (2004). Evaluating co-teaching as a means for successful inclusion of students with disabilities in a rural district. Rural Special Education Quarterly, 23(3), 3-14.

YILDIRIM, A. ve ŞIMŞSK, H. (2011). Nitel araştırma yöntemleri (8. Baskı). Ankara: Seçkin Yayıncılık.

YOON-SUK, H. (2010) Attitudes towards inclusion: gaps between belief and practice. International Journal of Special Education, 26(1), 136-146.

ZAMBELLI, F., and BONNI, R. (2004). Beliefs of teachers in Italian schools concerning the inclusion of disabled students: A Q-sort analysis. European Journal of Special Needs Education, 19(3), 351-364. 